\title{
The general pharmacy work explored in The Netherlands
}

\author{
Mark P. Mobach
}

Published online: 1 February 2008

(C) Springer Science+Business Media B.V. 2008

\section{Erratum to: Pharm World Sci}

\section{DOI 10.1007/s11096-007-9186-z}

Author's name should be read as Mark P. Mobach instead of M. P. Mark as indicated on the original publication (Doi: 10.1007/s11096-007-9186-z).

The online version of the original article can be found under doi:10.1007/s11096-007-9186-z.

M. P. Mobach ( $\square)$

Faculty of Economics and Business, University of Groningen,

P.O. Box 800, Landleven 5, Groningen 9700 AV,

The Netherlands

e-mail: m.p.mobach@rug.nl 